A NGE R'S PAS T 



\section{A NGER'S PAST}

\% The Social Uses of an Emotion in the Middle Ages

E D I T E D B

\section{BARBARA H. ROSENWEIN}

CORNELL UNIVERSITY PRESS 


\section{Copyright $\Subset 1998$ by Cornell University}

All rights reserved. Except for brief quotations in a review, this book, or parts thereof, must not be reproduced in any form without permission in writing from the publisher. For information, address Cornell University Press, Sage House, 5 I 2 East State Street, Ithaca, New York I4850.

First published 1998 by Cornell University Press.

First printing, Cornell Paperbacks, 1998.

Printed in the United States of America.

Cornell University Press strives to utilize environmentally responsible suppliers and materials to the fullest extent possible in the publishing of its books. Such materials include vegetable-based, low-VOC inks and acid-free papers that are also either recycled, totally chlorine-free, or partly composed of nonwood fibers.

Library of Congress Cataloging-in-Publication Data

Anger's past : the social uses of an emotion in the Middle Ages / edited by Barbara H. Rosenwein.

p. $\mathrm{cm}$.

Includes index.

ISBN 978-0-8014-8343-1 (pbk. : alk. paper)

I. Anger-History. 2. Social history-Medieval, 500-I 500. I. Rosenwein, Barbara H.

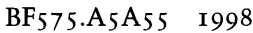

I 52.4'7'0902-dc2 I

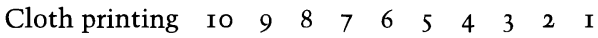

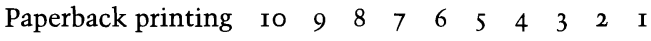

